\title{
Changes in compact bone microstructure of rats subchronically exposed to cadmium
}

\author{
Hana Duranova ${ }^{1 \dagger}$, Monika Martiniakova $^{1 \dagger}$, Radoslav Omelka ${ }^{2 \dagger}$, Birgit Grosskopf $^{3 *}$, Ivana Bobonova ${ }^{1 \dagger}$ \\ and Robert Toman ${ }^{4+}$
}

\begin{abstract}
Background: Chronic exposure to cadmium (Cd), even at low concentrations, has an adverse impact on the skeletal system. Histologically, primary and secondary osteons as basic structural elements of compact bone can also be affected by several toxicants leading to changes in bone vascularization and mechanical properties of the bone. The current study was designed to investigate the effect of subchronic peroral exposure to $\mathrm{Cd}$ on femoral bone structure including histomorphometry of the osteons in adult male rats.

In our study, 20 one-month-old male Wistar rats were randomly divided into two experimental groups. In the first group, young males received a drinking water containing $30 \mathrm{mg}$ of $\mathrm{CdCl}_{2} / \mathrm{L}$, for 90 days. Ten one-month-old males without $\mathrm{Cd}$ intoxication served as a control group. After 90 days of daily peroral exposure, body weight, femoral weight, femoral length, cortical bone thickness and histological structure of the femora were analysed.

Results: We found that subchronic peroral application of $\mathrm{Cd}$ had no significant effect on body weight, femoral length and cortical bone thickness in adult rats. On the other hand, femoral weight was significantly increased $(P<0.05)$ in $C d$-intoxicated rats. These rats also displayed different microstructure in the middle part of the compact bone where vascular canals expanded into central area of substantia compacta and supplied primary and secondary osteons. Additionally, a few resorption lacunae which are connected with an early stage of osteoporosis were identified in these individuals. Histomorphometrical evaluations showed that all variables (area, perimeter, maximum and minimum diameter) of the primary osteons' vascular canals, Haversian canals and secondary osteons were significantly decreased $(P<0.05)$ in the $C d$ group rats. This fact points to alterations in bone vascularization.

Conclusions: Subchronic peroral exposure to Cd significantly influences femoral weight and histological structure of compact bone in adult male rats. It induces an early stage of osteoporosis and causes reduced bone vascularization. Histomorphometrical changes of primary and secondary osteons allow for the conclusion that the bone mechanical properties could be weakened in the Cd group rats. The current study significantly expands the knowledge on damaging action of $\mathrm{Cd}$ on the bone.
\end{abstract}

Keywords: Compact bone, Cadmium, Rat, Osteoporosis

\section{Background}

Cadmium (Cd) is considered as one of the most toxic heavy metals [1]. Adverse effects of this non-essential metal are dependent on dose, route of administration, gestational age, species, and animal strain [2].

Bone is one of the target organs for Cd toxicity [3,4]. Various changes in the skeletal system characterized by

\footnotetext{
* Correspondence: birgit.grosskopf@biologie.uni-goettingen.de

${ }^{\dagger}$ Equal contributors

${ }^{3}$ Institute of Zoology and Anthropology, Georg-August University, 37073

Göttingen, Germany

Full list of author information is available at the end of the article
}

osteopenia, osteoporosis, and/or osteomalacia with increased incidence of bone fractures belong to the main unfavorable health effects of chronic environmental and occupational exposure to $\mathrm{Cd}$ [5-7]. The results obtained by Brzóska and Moniuszko-Jakoniuk [8] have shown that chronic, even low-level exposure to $\mathrm{Cd}$ disturbs bone metabolism during skeletal development and maturity by affecting bone turnover most probably through a direct influence on bone formation and resorption, and indirectly via disorders in calcium (Ca) metabolism. Besides interfering with $\mathrm{Ca}, \mathrm{Cd}$ also alters the metabolism of other metals essential for bone health [9]. For 
instance, $\mathrm{Cd}$ decreases zinc $(\mathrm{Zn})$ concentration in bones and inhibits activities of $\mathrm{Zn}$-dependent enzymes, such as alkaline phosphatase (it plays an important role in bone mineralization) $[10,11]$ and superoxide dismutase (SOD, is significant in bone antioxidant defense system) [10]. Galicka et al. [12] have reported that receiving of $50 \mathrm{mg}$ $\mathrm{Cd} / \mathrm{L}$ in drinking water for six months influenced the collagen content and its solubility in the femoral bone of female rats. Any disturbances in collagen metabolism result in the formation of low-quality bone tissue susceptible to deformation and fractures [13].

The damaging action of $\mathrm{Cd}$ on the rat skeleton during chronic exposure and its possible mechanisms have been extensively studied and reported by other researches; however, a detailed histological analysis of compact bone including histomorphometrical evaluations of primary and secondary osteons after subchronic peroral administration of $\mathrm{Cd}$ in rats had not been done prior to our experiment. In general, individual osteon morphology reflects changes in formation and resorption of bone, thus histomorphometrical analyses may give important information about the reorganization process in the bone also in stress situation, e.g. intoxication with various xenobiotics. Therefore, the aim of the present study was to analyse changes in macroscopical structure of femoral bones, and also in qualitative and quantitative histological characteristics of compact bone in rats subchronically exposed to $\mathrm{Cd}$ in their drinking water. In the case of potential alterations, the hypothesis of toxic effects of $\mathrm{Cd}$ on femoral bone structure, mechanical properties and vascularization of investigated bones will be described.

\section{Methods}

\section{Animals}

Our experiment was conducted on 20 one-month-old male Wistar rats obtained from the accredited experimental laboratory (number SK PC 50004) of the Slovak University of Agriculture in Nitra. Generally, the laboratory rat is the preferred animal for most researchers. Its skeleton has been studied extensively in various experimental protocols leading to bone loss, including hormonal interventions, immobilization, and dietary manipulations. Although there are several limitations to its similarity to the human condition, these can be overcome through detailed knowledge of its specific traits or with certain techniques [14]. We used the males because they are less susceptible to skeletal damage than females [15-18]. The rats were housed individually in plastic cages under constant temperature $\left(20-22^{\circ} \mathrm{C}\right)$, humidity $(55 \pm 10 \%)$, and 12 / $12 \mathrm{~h}$ cycle of light and darkness with access to food (feed mixture M3, Machal, Bonargo, Czech Republic) and drinking water ad libitum. We used cages Tecniplast 2154 F (Italy) which comply with the Government Regulation No. 23/2009. The cage disposed dimensions $480 \times$
$265 \times 210 \mathrm{~mm}$, with a floor area $940 \mathrm{~cm}^{2}$. We used wood chips as bedding material with paper rolls which enriched the living-space of animals. The clinically healthy experimental animals were randomly divided into two groups, of ten animals each. In the first group ( $\mathrm{Cd}$ group), young males were dosed with a daily $\mathrm{Cd}$ intake of $30 \mathrm{mg} \mathrm{CdCl} / \mathrm{L}$ in drinking water for 90 days. The second group (control group; $\mathrm{n}=10$ ) without $\mathrm{Cd}$ intoxication served as a control. The water consumption was daily monitored during the whole experiment. Since Cd absorption from the gastrointestinal tract in rats is lower than in humans [3], these animals need higher $\mathrm{Cd}$ doses to reach its concentration in the body similar to those noted in humans [19]. The concentration of $\mathrm{Cd}(30 \mathrm{mg} \mathrm{CdCl} / \mathrm{L}$ in drinking water; chosen on the basis of studied literature and our previous experiments with tested dose-response effects) was high enough to reach a toxicity level but also safe enough to prevent animal mortality (non-lethal dose) [3,4,18,20-22]. The daily dose of $\mathrm{Cd}$ in the $\mathrm{Cd}$ group was 0.596$0.597 \mathrm{mg} / \mathrm{kg}$ body weight (bw), which reflects the exposure in humans inhabiting moderately contaminated areas or via cigarette smoking (0.238-0.977 mg/kg bw) [18].

All procedures were approved by the Animal Experimental Committee of the Slovak Republic.

\section{Procedures}

At the end of 90 days, all rats were euthanized, weighed and their femurs were used for macroscopical and microscopical analyses. The right femurs were weighed on analytical scales with an accuracy of $0.01 \mathrm{~g}$ and the femoral length was measured with a sliding instrument. For histological analyses, the right femurs were sectioned at the midshaft of the diaphysis and the segments were fixed in HistoChoice fixative (Amresco, USA). The segments were then dehydrated in increasing grades (40 to 100\%) of ethanol and embedded in Biodur epoxy resin (Günter von Hagens, Heidelberg, Germany) according to the method described by Martiniaková et al. [23]. Transverse thin sections $(70-80 \mu \mathrm{m})$ were prepared with a sawing microtome (Leitz 1600, Leica, Wetzlar, Germany) and fixed onto glass slides by Eukitt (Merck, Darmstadt, Germany) [24]. The qualitative histological characteristics of the compact bone were determined according to the internationally accepted classification systems of Enlow and Brown [25] and Ricqlés et al. [26], who classified bone tissue into three main categories: primary vascular tissue, non-vascular tissue and Haversian bone tissue. Various patterns of vascularization can occur in primary vascular bone tissue: longitudinal, radial, reticular, plexiform, laminar, lepidosteoid, acellular, fibriform and protohaversian. There are three subcategories identified in Haversian bone tissue: irregular, endosteal and dense. The quantitative (histomorphometrical) variables were assessed using the software Motic Images Plus 2.0 ML (Motic China Group Co., Ltd.). 
We measured area, perimeter and the minimum and maximum diameters of primary osteons' vascular canals, Haversian canals and secondary osteons in all views (i.e., anterior, posterior, medial and lateral) of the thin sections in order to minimize inter-animal differences. Secondary osteons were distinguished from primary osteons (i.e., primary vascular canals) on the basis of the welldefined peripheral boundary (cement line) between the osteon and the surrounding tissue. Diaphyseal cortical bone thickness was also measured by Motic Images Plus 2.0 ML software. Twenty random areas were selected, and average thickness was calculated for each femur.

\section{Statistics}

Statistical analysis was performed using SPSS 8.0 software. All data were expressed as mean \pm standard deviation (SD). The unpaired Student's $T$-test was used for establishing statistical significance $(P<0.05)$ between $\mathrm{Cd}$ and control groups of rats.

\section{Results}

Macroscopical differences

Body weight, femoral length and cortical bone thickness were unchanged in rats exposed to $\mathrm{Cd}$ as compared to the control group. On the contrary, femoral weight was significantly increased $(P<0.05)$ in $C d$-intoxicated rats (Table 1).

\section{Microscopical differences}

Diaphysis of all femurs from the control rats had the following microstructure in common. Endosteal borders were formed by non-vascular bone tissue in all views (anterior, posterior, medial and lateral) of the thin sections. This type of bone tissue contained cellular lamellae and osteocytes without occurrence of primary and/or secondary osteons. Areas of primary vascular radial bone tissue (formed by branching or non-branching vascular canals radiating from the marrow cavity) were also identified in anterior, posterior and lateral views. Some primary and secondary osteons were exceptionally found in anterior and posterior views near endosteal surfaces. The occurrence of the osteons (primary and secondary) was also identified in middle parts of substantia compacta. The periosteal border was again composed of non-vascular bone tissue, mainly in the anterior and posterior views (Figure 1).

The rats exposed to $\mathrm{Cd}$ displayed a similar microarchitecture to that of the control rats, except for the middle part of the compact bone in the medial and lateral views. In these views, primary vascular radial bone tissue occurred because vascular canals expanded from endosteal border into central area of the bone and supplanted primary and secondary osteons. Therefore, a smaller number of the osteons was observed in Cd-intoxicated rats. In these rats, we identified a few resorption lacunae near endosteal surfaces (mainly in antero-medial and posteromedial views) which are connected with an early stage of osteoporosis (Figure 2).

For the quantitative histological characteristics, 841 vascular canals of primary osteons, 435 Haversian canals and 435 secondary osteons were measured in total. The results are summarized in Table 2 . We have found that subchronic peroral exposure to $\mathrm{Cd}$ significantly affects the sizes of primary and secondary osteons in male rats. All measured variables (area, perimeter, maximal and minimal diameter) of the primary osteons' vascular canals, Haversian canals and secondary osteons were significantly lower $(P<0.05)$ in rats from the $C d$ group as compared to those of the control one.

\section{Discussion}

Cadmium is an environmental pollutant that causes serious toxicity in humans and animals [4]. As a response to this metal toxicity, differences in the weight of various organs were identified after a long-term accumulation of $\mathrm{Cd}$ $[27,28]$. The increase in the femoral weight due to the subchronic exposure to $\mathrm{Cd}$ indicates a stimulating effect of this metal on the bone weight. Although $\mathrm{Cd}$ is not essential element for growth and development in mammals, it generally follows the metabolic pathways of some essential elements, such as Zn, primarily due to similar physicochemical properties and similar affinities for sulfhydryl groups [29,30]. According to Sigel et al. [31], the replacement of $\mathrm{Zn}^{2+}$ with $\mathrm{Cd}^{2+}$ in many enzymes and transcription factors may induce aberrant gene expression, resulting in the stimulation of cell proliferation.

Table 1 Body weight, femoral weight, femoral length and cortical bone thickness in adult male rats subchronic exposed to $30 \mathrm{mg}$ of $\mathrm{CdCl}_{2} / \mathrm{L}$ in drinking water for 90 days (Cd group) and the control rats (control group)

\begin{tabular}{|c|c|c|c|c|c|}
\hline Group & $\mathbf{N}$ & Body weight (g) & Femoral weight $(\mathrm{g})$ & Femoral length $(\mathrm{cm})$ & Cortical bone thickness $(\mathrm{mm})$ \\
\hline Control group & 10 & $405 \pm 52.65$ & $1.05 \pm 0.17$ & $3.94 \pm 0.09$ & $0.575 \pm 0.048$ \\
\hline Cd group & 10 & $422.5 \pm 27.21$ & $1.27 \pm 0.14$ & $3.99 \pm 0.14$ & $0.573 \pm 0.048$ \\
\hline \multirow[t]{3}{*}{$T$-test } & & NS & $t=3.123$ & NS & NS \\
\hline & & & $\mathrm{df}=18$ & & \\
\hline & & & $P=0.006$ & & \\
\hline
\end{tabular}




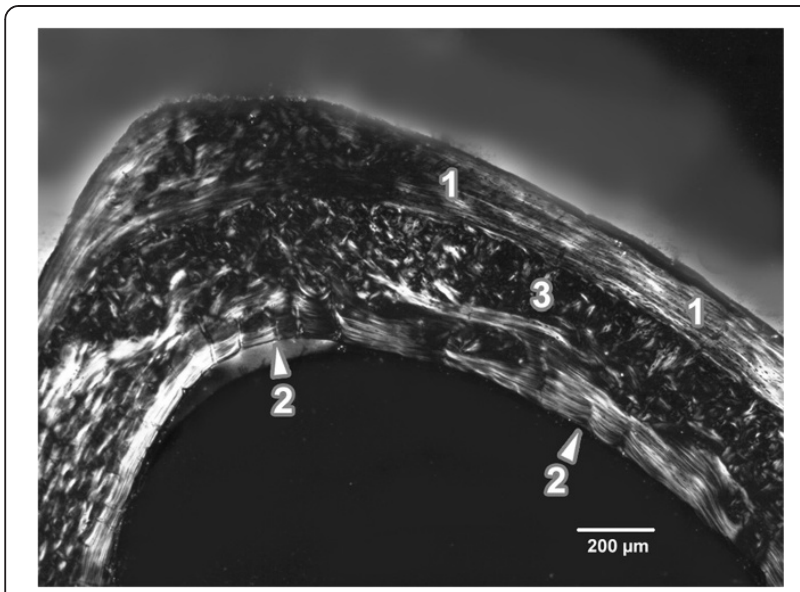

Figure 1 Microscopic structure of compact bone in rat from the control group. 1- non-vascular bone tissue. 2- vascular canals radiating from marrow cavity. 3- primary and secondary osteons in the middle part of compact bone.

Rat experiments indicate that oral ingestion of $\mathrm{Cd}$ through drinking water leads to an accumulation of $\mathrm{Cd}$ into the bone as it has also been observed in our study (Cd concentrations in the control and $\mathrm{Cd}$ groups were $0.92 \pm$ $0.21 \mathrm{mg} / \mathrm{kg}$ dry weight $(\mathrm{dw}), 1.33 \pm 0.18 \mathrm{mg} / \mathrm{kg} \mathrm{dw}$, respectively). In accordance with our results, Cd-induced increase in a weight of liver, kidney and spleen has also been mentioned in rats subcutaneously exposed to $2.0 \mathrm{mg}$ $\mathrm{CdCl}_{2} / \mathrm{kg}$ (three days/week or daily) for 28 or 21 days, respectively $[27,28]$. In contrast, the results obtained by Brzóska et al. [18] have shown that the exposure to relatively high doses of Cd (2.073-10.445 mg/kg bw) in drinking water for 12 months resulted in a significantly decreased femoral weight of adult male rats. Therefore, it

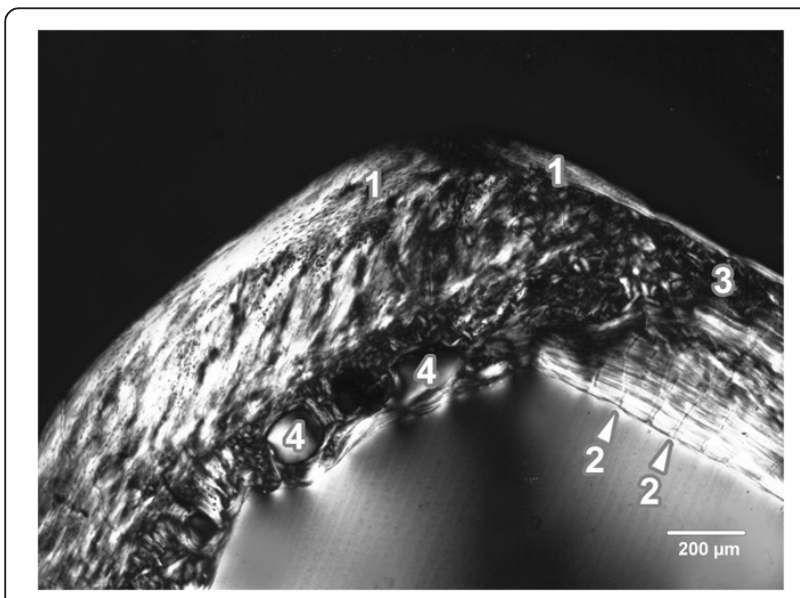

Figure 2 Microscopic structure of compact bone in rat from the Cd group. 1- non-vascular bone tissue. 2- enormous vascular canals radiating from marrow cavity. 3- smaller number of primary and secondary osteons in the middle part of compact bone. 4- resorption lacunae near endosteal surface. can be concluded that the impact of $\mathrm{Cd}$ on the weight of various organs (including bone) is dose-dependent.

We have found no significant differences for body weight and femoral length between the both groups of rats. Similarly, no demonstrable changes in the body weight [32,33] and femoral length [19] have also been reported in adult male rats after their exposure to 5 or $50 \mathrm{mg} \mathrm{Cd} / \mathrm{L}$ in drinking water for 12 months.

In general, the thickness of cortical bone is an important parameter in the evaluation of cortical bone quality and strength. According to Garn et al. [34], cortical thickness of femoral shaft is a good measuring parameter for evaluation of bone mass. We have found no significant differences in cortical bone thickness between rats from the $\mathrm{Cd}$ group and those of the control one. In the study by Comelekoglu et al. [13], cortical thickness in the femoral diaphysis was also unchanged in adult female rats after a common low intraperitoneal administration of Cd for 18 weeks.

Our findings from the qualitative histological analysis of compact bone in rats from the control group correspond with those reported by other researches [35-38]. The basic structural pattern of the bone tissue was non-vascular. In addition, some areas of primary vascular radial and/or irregular Haversian bone tissues were observed. However, there was no evidence of true Haversian intracortical bone remodeling in our rats. It is generally known that aged rats and mice lack true Haversian cortical bone remodeling under physiological conditions but not cancellous bone remodeling activity $[14,37,39,40]$. Therefore, some secondary osteons can be observed in their long bones (mainly near endosteal border). In our study, the newly formed remodeling units within compact bone originated from the endocortical surface and extended deeply into the underlying compact bone. The same results have also been documented in the study of Reim et al. [37] for thirteenmonth-old male rats.

On the other hand, prolonged intake of moderate dose of $\mathrm{Cd}$ induced changes in the middle part of substantia compacta (in medial and lateral views) in rats from the $\mathrm{Cd}$ group, where primary vascular radial bone tissue was found. Formation of this type of bone tissue may be explained as an adaptive response of the bone to $\mathrm{Cd}$ toxicity in order to protect bone tissue against death of cells and subsequent necrosis. It is known that $\mathrm{Cd}$ induces apoptosis in osteoblast-like cells [41-43], osteoblasts [44,45] and human tumor-derived Saos-2 osteoblasts [46]. Disappearance of the Haversian canal system, which was replaced by a large quantity of degenerated and necrotic tissue, have been demonstrated in the study by Li et al. [47] for ovariectomized rats after a longterm $\mathrm{Cd}$ administration.

Additionally, we identified a few resorption lacunae near endosteal surfaces in $\mathrm{Cd}$-exposed rats which signalize an 
Table 2 Data of the primary osteons' vascular canals, Haversian canals and secondary osteons in adult male rats subchronic exposed to $30 \mathrm{mg}$ of $\mathrm{CdCl}_{2} / \mathrm{L}$ in drinking water for 90 days (Cd group) and the control rats (control group)

\begin{tabular}{|c|c|c|c|c|c|c|}
\hline Measured structure & Group & $\mathrm{N}$ & Area $\left(\mu \mathrm{m}^{2}\right)$ & Perimeter $(\mu \mathrm{m})$ & Max. diameter $(\mu \mathrm{m})$ & Min. diameter $(\mu \mathrm{m})$ \\
\hline \multirow[t]{5}{*}{ Primary osteons' vascular canals } & Control group & 436 & $393.49 \pm 123.05$ & $71.58 \pm 12.37$ & $12.87 \pm 2.68$ & $9.62 \pm 1.68$ \\
\hline & Cd group & 405 & $341.39 \pm 65.77$ & $66.74 \pm 7.27$ & $11.77 \pm 1.08$ & $9.29 \pm 1.13$ \\
\hline & $T$-test & & $t=7.732$ & $t=6.975$ & $t=7.007$ & $t=3.385$ \\
\hline & & & $d f=674.963$ & $d f=712.451$ & $d f=767.944$ & $d f=768.604$ \\
\hline & & & $P=0.001$ & $P=0.001$ & $P=0.001$ & $P=0.001$ \\
\hline \multirow[t]{5}{*}{ Haversian canals } & Control group & 208 & $428.3 \pm 75.75$ & $74.94 \pm 7.3$ & $13.04 \pm 1.56$ & $10.73 \pm 1.17$ \\
\hline & Cd group & 227 & $384.94 \pm 73.23$ & $70.9 \pm 6.94$ & $12.52 \pm 1.67$ & $9.84 \pm 1.31$ \\
\hline & $T$-test & & $t=6.403$ & $t=6.403$ & $t=3.533$ & $t=7.880$ \\
\hline & & & $\mathrm{df}=483$ & $d f=483$ & $\mathrm{df}=483$ & $\mathrm{df}=483$ \\
\hline & & & $P=0.001$ & $P=0.001$ & $P=0.001$ & $P=0.001$ \\
\hline \multirow[t]{5}{*}{ Secondary osteons } & Control group & 208 & $6408.74 \pm 1820.97$ & $292.98 \pm 39.59$ & $51.64 \pm 8.17$ & $39.51 \pm 6.2$ \\
\hline & Cd group & 227 & $4583.64 \pm 1326.92$ & $240.60 \pm 35.32$ & $41.50 \pm 6.92$ & $34.6 \pm 5.32$ \\
\hline & $T$-test & & $t=12.467$ & $t=15.399$ & $t=14.651$ & $t=9.294$ \\
\hline & & & $d f=408.155$ & $d f=483$ & $\mathrm{df}=445.501$ & $d f=448.265$ \\
\hline & & & $P=0.001$ & $P=0.001$ & $P=0.001$ & $P=0.001$ \\
\hline
\end{tabular}

$\mathrm{N}$ : number of measured structures.

early stage of osteoporosis or a presence of an inflammatory process. However, the inflammatory process is characterized by newly built bone formation on periosteal surface (periosteal apposition) [48] which has not been observed in our bone samples. Therefore, the presence of resorption lacunae in rats from the $\mathrm{Cd}$ group could be associated only with an early stage of osteoporosis. Several experimental studies revealed that $\mathrm{Cd}$ stimulates the differentiation and activity of osteoclasts and inhibits differentiation and activity of osteoblasts [41,49-51]. These effects cause an uncoupling of the normal balance between bone formation and bone resorption resulting in decreased bone mineral density and increased fracture incidence [52], i.e. typical manifest symptoms of osteoporosis. In addition, it has been demonstrated that $\mathrm{Cd}$ can stimulate osteoblasts to secrete prostaglandin E2 in vitro [53]. It also increases serum parathyroid hormone levels [54] which are connected with osteoclast formation. Moreover, exposure to low levels of $\mathrm{Cd}$ has also been associated with increased urinary $\mathrm{Ca}$ excretion and subsequent skeletal demineralization, i.e. effects that may accelerate bone loss and increase bone fragility $[55,56]$.

The vascular (also Haversian) canal constriction identified in rats from the Cd group could be associated with structural changes of blood vessels due to toxic effect of Cd. Each Haversian canal contains blood vessels and nerves supported by loose connective tissue [57]. Blood vessels are also present in vascular canals of primary osteons [58]. In general, the vascular system is a critical target of metal toxicity and actions of metals on the vascular system may play important roles in mediating the pathophysiological effects of metals in specific target organs [59]. It is well known that Cd causes morphological alterations and dysfunction in blood vessels leading to hypertension [60]. According to Martynowicz et al. [61], mechanisms of the vascular effect of Cd vary and involve nervous, hormone and intracellular signaling pathways. The results of recent studies [61-63] showed an inhibitory impact of $\mathrm{Cd}$ on synthesis and/or releasing of endotheliumderived vasoactive substances (e.g. nitric oxide - NO). Decreased NO concentration in vessels of hypertensive rats can also be associated with increased superoxide anions as a result of $\mathrm{Cd}$-induced oxidative stress [64]. On the other hand, exposure of endothelial cells to $\mathrm{Cd}$ significantly increased the secretion of vasoconstrictors, such as angiotensin II and endothelin-I [65]. The important role in physiological as well as pathological processes of bone tissue plays an angiogenesis (i.e. formation of new blood vessels) which is modulated by growth factors, cytokines, adhesion molecules, integrins and enzymes [66]. According to Prozialeck et al. [67] and Straub et al. [68], angiogenesis has a key role in homeostatic response to various toxicant exposures. Kim et al. [60] found that high concentrations of $\mathrm{Cd}(>10 \mu \mathrm{m})$ inhibit vascular endothelial growth factor (VEGF) expression and disrupt the growth of blood vessels. Besides VEGF, adverse effect of $\mathrm{Cd}$ on the function of VE-cadherin has also been reported [69]. The results by Kolluru et al. [70] demonstrate that $\mathrm{Cd}$ can directly inhibit endothelial migration and tube formation. We suppose that all these aspects could contribute to vascular (Haversian) canal constriction in our rats exposed to $\mathrm{Cd}$. 
All variables of the secondary osteons had also lower values in Cd-intoxicated rats. Generally, it is known that heavy metals (including $\mathrm{Cd}$ ) are adsorbed and stored within bones [71]. In bones, $\mathrm{Cd}$ may be incorporated into hydroxyapatite (HA) crystals instead of Ca [32,72,73], making them considerably resistant to subsequent dissolution [74]. The results by Blumenthal et al. [72] showed that $\mathrm{Cd}$ incorporation into the HA introduced little strain in the lattice but resulted in a decreasing $\mathrm{C}$-axis spacing and corresponding crystal size decrease in the $\mathrm{C}$-axis direction. HA crystals, as most important mineral components of bones, are aligned with their long axis parallel to the collagen fiber axis creating concentric lamellae of the secondary osteons $[75,76]$. On the basis of these findings we speculate that a decrease in HA crystals could partially contribute to the decreased size of the secondary osteons in rats from the $\mathrm{Cd}$ group. According to Brzóska and Moniuszko-Jakoniuk [32], the metal incorporated into HA crystals affects consequently bone properties. In respect to altered bone mineral crystal size, bones consisting only small crystals have weakened the mechanical properties of the bone composite [77]. Furthermore, Cd in HA crystals can promote bone resorption and cause osteomalacia or osteoporosis [78,79].

Our study demonstrates that subchronic exposure to $\mathrm{Cd}$ had a significant impact on femoral weight and compact bone microstructure in adult male rats. The histomorphometrical changes were identified on levels of primary osteons' vascular canals, Haversian canals and secondary osteons. Due to increasing trend of $\mathrm{Cd}$ environmental contamination and human exposition, our findings are of high importance and could also have practical implications in humans. Our results with the moderate dose of $\mathrm{Cd}$ in rats, reflecting possible $\mathrm{Cd}$ exposure in humans in specific conditions, give a real indication that the same changes in bone microstructure may also occur in exposed humans. The environmental $\mathrm{Cd}$ contamination, as well as improper living habits, such as cigarette smoking, can lead to damages and diseases of bones. Identifying environmental factors (such as $\mathrm{Cd}$ ) and possible mechanisms that contribute to bone loss, decreased bone vascularization and weakening of mechanical bone properties is the first step to prevention of skeletal damages in humans.

\section{Conclusions}

The current study revealed that subchronic peroral administration of $30 \mathrm{mg} \mathrm{CdCl} / \mathrm{L}$ in drinking water for 90 days has the significant impact on femoral weight and both the qualitative and quantitative histological characteristics of compact bone in adult male rats. It induces an early stage of osteoporosis, alterations in bone vascularization and potentially diminished bone mechanical properties. Our study can be involved in creation a comprehensive novel insight into bone toxicology in experimental animals.
Competing interests

The authors declare that they have no competing interests.

\section{Authors' contributions}

HD was responsible for quantitative histological analysis of bones and writing an article. MM was responsible for qualitative histological analysis of bones and helped with writing an article. RO was responsible for the statistical analysis. BG was responsible for preparation of histological sections. IB was responsible for macroscopic analysis of bones and photodocumentation of histological sections. RT was responsible for animal care and sampling of femora. All authors read and approved the final manuscript.

\section{Acknowledgements}

The study was supported by the grants KEGA 025UKF-4/2012, 035UKF-4/2013 (Ministry of Education, Slovakia). This article was written during realization of the project MARKERY No.26220220033 supported by the Operational

Programme Research and Development funded from the European Regional Development Fund.

\section{Author details}

${ }^{1}$ Department of Zoology and Anthropology, Constantine the Philosopher University, 94974 Nitra, Slovakia. ${ }^{2}$ Department of Botany and Genetics, Constantine the Philosopher University, 94974 Nitra, Slovakia. ${ }^{3}$ Institute of Zoology and Anthropology, Georg-August University, 37073 Göttingen, Germany. ${ }^{4}$ Department of Veterinary Sciences, Slovak University of Agriculture, 94976 Nitra, Slovakia.

Received: 21 December 2013 Accepted: 8 September 2014

Published online: 24 September 2014

\section{References}

1. Brzóska MM, Moniuszko-Jakoniuk J: Interactions between cadmium and zinc in the organism. Food Chem Toxicol 2001, 39:967-980.

2. Record JR, Dresosti IE, Manuel SJ, Buckling RA: Interactions of cadmium and zinc in cultures rat embryos. Life Sci 1982, 31:2735-2743.

3. World Health Organization (WHO)/International Programme on Chemical Safety (IPCS): Cadmium, Environmental Health Criteria 134. Geneva: WHO; 1992.

4. Agency for Toxic Substances and Disease Registry (ATSDR): Toxicological Profile for Cadmium. Atlanta, GA: U.S. Department of Health and Human Services, Public Health Service; 2012.

5. Aoshima K, Fan J, Cai Y, Katoh T, Teranishi H, Kasuya M: Assessment of bone metabolism in cadmium-induced renal tubular dysfunction by measurements of biochemical markers. Toxicol Lett 2003, 136:183-192.

6. Wang $H$, Zhu G, Shi Y, Weng S, Jin T, Kong Q, Nordberg GF: Influence of environmental cadmium exposure on forearm bone density. J Bone Miner Res 2003, 18:553-560.

7. Brzóska MM, Moniuszko-Jakoniuk J: Low-level lifetime exposure to cadmium decreases skeletal mineralization and enhances bone loss in aged rats. Bone 2004, 35:1180-1191.

8. Brzóska MM, Moniuszko-Jakoniuk J: Disorders in bone metabolism of female rats chronically exposed to cadmium. Toxicol Appl Pharmacol 2005, 202:68-83.

9. Noël L, Guérin T, Kolf-Clauw M: Subchronic dietary exposure of rats to cadmium alters the metabolism of metals essential to bone health. Food Chem Toxicol 2004, 42:1203-1210.

10. Brzóska MM, Rogalska J, Kupraszewicz E: The involvement of oxidative stress in the mechanisms of damaging cadmium action in bone tissue: a study in a rat model of moderate and relatively high human exposure. Toxicol Appl Pharmacol 2011, 250:327-335.

11. Brzóska MM: Low-level chronic exposure to cadmium enhances the risk of long bone fractures: a study on a female rat model of human lifetime exposure. J Appl Toxicol 2012, 32:34-44.

12. Galicka A, Brzóska MM, Średzińska K, Gindzienski A: Effect of cadmium on collagen content and solubility in rat bone. Acta Biochim Pol 2004, 51:825-829.

13. Comelekoglu U, Yalin S, Bagis S, Ogenler O, Sahin NO, Yildiz A, Coskun B, Hatungil $R$, Turac A: Low-exposure cadmium is more toxic on osteoporotic rat femoral bone: mechanical, biochemical, and histopathological evaluation. Ecotox Environ Safe 2007, 66:267-271. 
14. Lelovas PP, Xanthos TT, Thoma SE, Lyritis GP, Dontas IA: The laboratory rats as an animal model for osteoporosis research. Comp Med 2008, 58:424-430

15. Bernstein CN, Seeger LL, Sayre W, Anton PA, Artinian L, Shanahan F: Decreased bone density in inflammatory bowel disease is related to corticosteroid use and not disease diagnosis. J Bone Miner Res 1995, 10:250-256

16. Marystone JF, Barrett-Connor EL, Morton DJ: Inhaled and oral corticosteroids: their effects on bone mineral density in older adults. Am J Public Health 1995, 85:1693-1695.

17. Riggs BL, Melton III LJ, Robb RA, Camp JJ, Atkinson EJ, Peterson JM, Rouleau PA, McCollough CH, Bouxsein ML, Khosla S: Population based study of age and sex differences in bone volumetric density, size, geometry, and structure at different skeletal sites. J Bone Miner Res 2004, 19:1945-1954.

18. Brzóska MM, Majewska K, Kupraszewicz E: Effects of low, moderate and relatively high chronic exposure to cadmium on long bones susceptibility to fractures in male rats. Environ Toxicol Pharmacol 2010, 29:235-245

19. Brzóska MM, Rogalska J, Galazyn-Sidorczuk M, Jurczuk M, Roszczenko A, Kulikowska-Karpińska E, Moniuszko-Jakoniuk J: Effect of zinc supplementation on bone metabolism in male rats chronically exposed to cadmium. Toxicology 2007, 237:89-103.

20. Toman R, Golian J, Šiška B, Massáyni P, Lukáč N, Adamkovičová M: Cadmium and selenium in animal tissues and their interactions after an experimental administration to rats. Slovak J Anim Sci 2009, 42:115-118.

21. Toman R, Adamkovicova M, Hluchý S, Cabaj M, Golian J, Massanyi P, Lukac N, Martiniakova M: Computer-assisted sperm motility analysis and sperm morphology changes after a peroral administration of diazinon and cadmium in rats. Arch Ind Hyg Toxicol 2012, 63:61.

22. Toman R, Adamkovičová M, Massáyni P, Cabaj M, Lukáč N, Martiniaková M, Omelka R: Cadmium and diazinon-induced changes in the rat testis structure after a peroral administration in drinking water. J Microb Biotech Food Sci 2012, 2:564-575

23. Martiniaková M, Omelka R, Grosskopf B, Sirotkin AV, Chrenek P: Sex-related variation in compact bone microstructure of the femoral diaphysis in juvenile rabbits. Acta Vet Scand 2008, 50:15

24. Martiniaková M, Omelka R, Jančová A, Stawarz R, Formicki G: Heavy metal content in the femora of yellow-necked mouse (Apodemus flavicollis) and wood mouse (Apodemus sylvaticus) from different types of polluted environment in Slovakia. Environ Monit Assess 2010, 171:651-660.

25. Enlow DH, Brown SO: A comparative histological study of fossil and recent bone tissues. Part I. Texas J Sci 1956, 8:405-412.

26. de Ricqlés AJ, Meunier FJ, Castanet J, Francillon-Vieillot H: Comparative microstructure of bone. In Bone 3, Bone Matrix and Bone Specific Products. Edited by Hall BK. Boca Raton: CRC Press; 1991:1-78.

27. Yamano T, Shimizu M, Noda T: Comparative effects of repeated administration of cadmium on kidney, spleen, thymus, and bone marrow in 2-, 4-, and 8-month-old male Wistar rats. Toxicol Sci 1998, 46:393-402.

28. Gaurav D, Preet S, Dua KK: Chronic cadmium toxicity in rats: treatment with combined administration of vitamins, amino acids, antioxidants and essential metals. J Food Drug Anal 2010, 18:464-470.

29. Anke M, Masaoka T, Arnhold W, Krause U, Groppel B, Schwarz S: The influence of a sulphur, molybdenum or cadmium exposure on the trace element status of cattle and pigs. Arch Anim Nutr 1989, 39:657-666.

30. McQueen CA: Comprehensive Toxicology. St. Louis, MO: Elsevier; 2010.

31. Sigel A, Sigel H, Sigel RKO: Cadmium: From Toxicity to Essentiality. Dordrecht: Springer Science + Bussines; 2013.

32. Brzóska MM, Moniuszko-Jakoniuk J: Bone metabolism of male rats chronically exposed to cadmium. Toxicol Appl Pharmacol 2005, 207:195-211.

33. Brzóska MM, Galazyn-Sidorczuk M, Rogalska J, Roszczenko A, Jurczuk M, Majewska K, Moniuszko-Jakoniuk J: Beneficial effect of zinc supplementation on biomechanical properties of femoral distal end and femoral diaphysis of male rats chronically exposed to cadmium. Chem-Biol Interact 2008, 171:312-324.

34. Garn SM, Rohmann CG, Nolan P: The developmental nature of bone changes during aging. Nutr Rev 1991, 49:176-178.

35. Enlow DH, Brown SO: A comparative histological study of fossil and recent bone tissues. Part III. Texas J Sci 1958, 10:187-230.
36. Martiniaková M, Grosskopf $B$, Vondráková M, Omelka R, Fabiš M: Observation of the microstructure of rat cortical bone tissue. Scripta Med 2005, 78:45-50.

37. Reim NS, Breig B, Stahr K, Eberle J, Hoeflich A, Wolf E, Erben RG: Cortical bone loss in androgen-deficient aged male rats is mainly caused by increased endocortical bone remodeling. J Bone Miner Res 2008, 23:694-704.

38. Martiniaková M, Omelka R, Grosskopf B, Mokošová Z, Toman R: Histological analysis of compact bone tissue in adult laboratory rats. Slovak J Anim Sci 2009, 42:56-59.

39. Baron $R$, Tross $R$, Vignery A: Evidence of sequential remodeling in rat trabecular bone: morphology, dynamic histomorphometry, and changes during skeletal maturation. Anat Rec 1984, 208:137-145.

40. Erben RG: Trabecular and endocortical bone surfaces in the rat: modeling or remodeling? Anat Rec 1996, 246:39-46.

41. Coonse KG, Coonts AJ, Morrison EV, Heggland SJ: Cadmium induces apoptosis in the osteoblast-like cell line, Saos-2. J Toxicol Environ Health A 2007, 70:575-581.

42. Lévesque M, Martineau C, Jumarie C, Moreau R: Characterization of cadmium uptake and cytotoxicity in human osteoblast-like MG-63 cells. Toxciol Appl Pharmacol 2008, 231:308-317.

43. Smith SS, Rodriguez Reyes J, Arbon KS, Harvey WA, Hunt LM, Heggland S: Cadmium-induced decrease in RUNX2 mRNA expression and recovery by the antioxidant $\mathrm{N}$-acetylcysteine (NAC) in the human osteoblast-like cell line, Saos-2. Toxicol in Vitro 2009, 23:60-66.

44. Brama M, Politi L, Santini P, Migliaccio S, Scandurra R: Cadmium-induced apoptosis and necrosis in human osteoblasts: role of caspases and mitogen-activated protein kinases pathways. J Endocrinol Invest 2012, 35:198-208.

45. Lizotte J, Abed E, Signor C, Malu DT, Cuevas J, Kevorkova O, SanchezDardon J, Satoskar A, Scorza T, Jumarie C, Moreau R: Expression of macrophage migration inhibitory factor by osteoblastic cells: protection against cadmium toxicity. Toxicol Lett 2012, 215:167-173.

46. Arbon KS, Christensen CM, Harvey WA, Heggland SJ: Cadmium exposure activates the ERK signaling pathway leading to altered osteoblast gene expression and apoptotic death in Saos-2 cells. Food Chem Toxicol 2012, 50:198-205

47. Li JP, Akiba T, Marumo F: Long-term, low-dose, cadmium-induced nephropathy with renal osteopathy in ovariectomized rats. J Toxicol Sci 1997, 22:185-198.

48. Schultz M: Light microscopic analysis in skeletal paleopathology. In Identification of Pathological Conditions in Human Skeletal Remains. Edited by Ortner DJ. Amsterdam: Academic Press; 2003:73-107.

49. Chen X, Zhu G, Gu S, Jin T, Shao C: Effects of cadmium on osteoblasts and osteoclasts in vitro. Environ Toxicol Pharmacol 2009, 28:232-236.

50. Chen X, Zhu G, Shao C, Jin T, Tan M, Gu S, Zhang Y, Xiao H: Effects of cadmium on bone microstructure and serum tartrate-resistant acid phosphatase 5b in male rats. Exp Biol Med 2011, 236:1298-1305.

51. Chen X, Wang G, Li X, Gan C, Zhu G, Jin T, Wang Z: Environmental level of cadmium exposure stimulates osteoclasts formation in male rats. Food Chem Toxicol 2013, 60:530-535.

52. Bhattacharyya $\mathrm{MH}$ : Cadmium osteotoxicity in experimental animals: mechanisms and relationship to human exposures. Toxicol Appl Pharmacol 2009, 238:258-265.

53. Suzuki Y, Morita I, Yamane $Y$, Murota S: Preventive effect of zinc against cadmium-induced bone resorption. Toxicology 1990, 62:27-34.

54. Nogawa K, Kobayashi E, Yamada Y, Honda R, Kido T, Tsuritani I, Ishizaki M: Parathyroid hormone concentration in the serum of people with cadmium-induced renal damage. Int Arch Occup Environ Health 1984, 54:187-193.

55. Wittman R, Hu H: Cadmium exposure and nephropathy in a 28-year-old female metals worker. Environ Health Perspect 2002, 110:1261-1266.

56. Jin T, Nordberg G, Ye T, Bo M, Wang H, Zhu G, Kong Q, Bernard A: Osteoporosis and renal dysfunction in a general population exposed to cadmium in China. Environ Res 2004, 96:353-359.

57. Watkins J: Structure and Function of the Musculoskeletal System. Illinois: Human Kinetics Publisher; 2010.

58. Greenlee DM, Dunnell RC: Identification of fragmentary bone from the Pacific. J Archaeol Sci 2010, 37:957-970. 
59. Prozialeck WC, Edwards JC, Nebert DW, Woods JM, Barchowskya A, Atchison W: The vascular system as a target of metal toxicity. Toxicol Sci 2008, 102:207-218.

60. Kim J, Lim W, Ko Y, Kwon H, Kim S, Kim O, Park G, Choi H, Kim O: The effects of cadmium on VEGF-mediated angiogenesis in HUVECs. J Appl Toxicol 2012, 32:342-349.

61. Martynowicz H, Skoczynska A, Wojakowska A, Turczyn B: Serum vasoactive agents in rats poisoned with cadmium. Int I Occup Med Environ Health 2004, 17:479-485.

62. Bilgen I, Oner G, Edremitlioglu M, Alkan Z, Cirrik S: Involvement of cholinoceptors in cadmium-induced endothelial dysfunction. J Basic Clin Physiol Pharmacol 2003, 14:55-76.

63. Skoczynska A, Martynowicz H: The impact of subchronic cadmium poisoning on the vascular effect of nitric oxide in rats. Hum Exp Toxicol 2005, 24:353-361.

64. Vega GW, Roson MI, Bellver A, Celentano MM, de la Riva IJ: Nitric oxide and superoxide anions in vascular reactivity of renovascular hypertensive rats. Clin Exp Hypertens 1995, 17:817-835.

65. Kusaka Y, Kelly RA, Williams GH, Kifor I: Coronary microvascular endothelial cells cosecrete angiotensin II and endothelin-1 via a regulated pathway. Am J Physiol Heart Circ Physiol 2000, 279:H1087-H1096.

66. Cenni E: Angiogenesis and bone regeneration. J Bone Joint Surg (Br) 2005, 87-B:58.

67. Prozialeck WC, Edwards JR, Woods JM: The vascular endothelium as a target of cadmium toxicity. Life Sci 2006, 79:1493-1506.

68. Straub AC, Stolz DB, Ross MA, Hernandez-Zavala A, Soucy NV, Klei LR, Barchowsky A: Arsenic stimulates sinusoidal endothelial cell capillarization and vessel remodeling in mouse liver. Hepatology 2007, 45:205-212.

69. Woods JM, Leone M, Klosowska K, Lamar PC, Shaknovsky TJ, Prozialeck WC: Direct antiangiogenic actions of cadmium on human vascular endothelial cells. Toxicol In Vitro 2008, 22:643-651.

70. Kolluru GK, Tamilarasan KP, Geetha Priya S, Durgha NP, Chatterjee S: Cadmium induced endothelial dysfunction: consequence of defective migratory pattern of endothelial cells in association with poor nitric oxide availability under cadmium challenge. Cell Biol Int 2006, 30:427-438,

71. Wiechula D, Jurkiewicz A, Loska K: An assessment of natural concentrations of selected metals in the bone tissues of the femur head. Sci Tot Environ 2008, 406:161-167.

72. Blumenthal NC, Cosma V, Skyler D, Legeros J, Walters M: The effect of cadmium on the formation and properties of hydroxyapatite in vitro and its relation to cadmium toxicity in the skeletal system. Calcif Tissue Int 1995, 56:316-322.

73. Robey P, Boskey A: Extracellular matrix and biomineralization of bone. In Primer on the Metabolic Bone Diseases and Disorders of Mineral Metabolism. 5th edition. Edited by Favus M. Washington DC: The American Society of Bone and Mineral Research; 2003:38-46.

74. Christoffersen J, Christoffersen MR, Larsen R, Rostrup E, Tingsgaard P, Andersen O, Grandjean P: Interaction of cadmium ions with calcium hydroxyapatite crystals: a possible mechanism contributing to the pathogenesis of cadmium-induced bone diseases. Calcif Tissue Int 1988, 42:331-339.

75. Boskey AL: The organic and inorganic matrices. In Bone Tissue Engineering. Edited by Hollinger JO, Einhorn TA, Doll BA, Sfeir C. Boca Raton: CRC Press; 2005:91-123.

76. Fonseca JE: Bone biology: from macrostructure to gene expression. Medicographia 2012, 34:142-148.

77. Boskey AL: Bone mineral crystal size. Osteoporos Int 2003, 14:S16-S21

78. Feldman SL, Cousins RJ: Influence of cadmium on the metabolism of 25hydroxycholecalciferol in chicks. Nutr Rep Int 1973, 8:251-260.

79. Hamilton DL, Smith MW: Cadmium inhibits calcium absorption by rat intestine [Proceeding]. J Physiol 1977, 265:54P-55P.

doi:10.1186/s13028-014-0064-0

Cite this article as: Duranova et al:: Changes in compact bone microstructure of rats subchronically exposed to cadmium. Acta Veterinaria Scandinavica 2014 56:64

\section{Submit your next manuscript to BioMed Central and take full advantage of:}

- Convenient online submission

- Thorough peer review

- No space constraints or color figure charges

- Immediate publication on acceptance

- Inclusion in PubMed, CAS, Scopus and Google Scholar

- Research which is freely available for redistribution

Submit your manuscript at www.biomedcentral.com/submit
C Biomed Central 